\title{
Use of a Copper- and Zinc-Modified Natural Zeolite to Improve Ethylene Removal and Postharvest Quality of Tomato Fruit
}

 \\ Norberto Abreu ${ }^{3}$, Federico Azzolina-Jury ${ }^{4}$ and Héctor Valdés ${ }^{2, *(1)}$ \\ 1 Departamento de Agroindustrias, Facultad de Ingeniería Agrícola, Universidad de Concepción, \\ Avenida Vicente Méndez 595, 3780000 Chillán, Chile; ambargomez@udec.cl (A.G.); cloyola@udec.cl (C.L.); \\ pmelin@udec.cl (P.M.) \\ 2 Laboratorio de Tecnologías Limpias, Facultad de Ingeniería, Universidad Católica de la Santísima \\ Concepción, Alonso de Ribera 2850,4030000 Concepción, Chile; vsolar@ucsc.cl \\ 3 Center of Waste Management and Bioenergy, BIOREN, Departamento de Ingeniería Química, \\ Facultad de Ingeniería y Ciencias, Universidad de la Frontera, Francisco Salazar 01145, \\ 4780000 Temuco, Chile; norberto.abreu@ufrontera.cl \\ 4 ENSICAEN, UNICAEN, CNRS, Laboratoire Catalyse et Spectrochimie, Normandie Université, \\ 14000 Caen, France; federico.azzolina-jury@ensicaen.fr \\ * Correspondence: jdebruij@udec.cl (J.d.B.); hvaldes@ucsc.cl (H.V.); Tel.: +56-42-220-8891 (J.d.B.); \\ +56-41-234-5044 (H.V.)
}

Received: 23 April 2020; Accepted: 1 June 2020; Published: 3 June 2020

\begin{abstract}
Ethylene stimulates ripening and senescence by promoting chlorophyll loss, red pigment synthesis, and softening of tomatoes and diminishes their shelf-life. The aim of this work was to study the performance of a novel copper- and zinc-based ethylene scavenger supported by ion-exchange on a naturally occurring zeolite by analyzing its ethylene adsorption capacity and the influence of ethylene scavenging on quality attributes during the postharvest life of tomatoes. The influence of copper- and zinc-modified zeolites on ethylene and carbon dioxide concentrations and postharvest quality of tomatoes was compared with unmodified zeolite. Interactions among ethylene molecules and zeolite surface were studied by diffuse reflectance infrared Fourier transform spectroscopy in operando mode. The percentage of ethylene removal after eight days of storage was $57 \%$ and $37 \%$ for the modified zeolite and pristine zeolite, respectively. The major ethylene increase appeared at 9.5 days for the modified zeolite treatment. Additionally, modified zeolite delayed carbon dioxide formation by six days. Zeolite modified with copper and zinc cations favors ethylene removal and delays tomato fruit ripening. However, the single use of unmodified zeolite should be reconsidered due to its ripening promoting effects in tomatoes at high moisture storage conditions, as water molecules block active sites for ethylene adsorption.
\end{abstract}

Keywords: adsorption; DRIFTS operando; ethylene scavenging; postharvest quality; tomato; zeolite

\section{Introduction}

Tomato fruit (Solanum lycopersicum L.) is one of the most consumed vegetables worldwide with a total production of about 182 million tons per year [1]. Tomatoes are climacteric fruit in which ripening is accompanied by a quickly increased respiration and ethylene production. Ethylene $\left(\mathrm{C}_{2} \mathrm{H}_{4}\right)$ is a simple, naturally produced plant-growth-regulating substance that has numerous effects during the postharvest life of fruit and vegetables. Ethylene stimulates ripening and senescence that may result in detrimental effects by promoting unwanted softening and a grainy structure in tomatoes [2]. 
In addition, ethylene accelerates pigment synthesis and chlorophyll loss in tomatoes [2]. Complete ripening within just a few days is not desirable and should be avoided because it limits commercial shelf-life of horticultural products by accelerating their quality loss. Commercial postharvest strategies are often based on avoiding the exposure of climacteric fruit to ethylene, attempting to minimize ethylene production, inhibit its action, and by the removal of $\mathrm{C}_{2} \mathrm{H}_{4}$ not only from the postharvest facilities but also from the inside of storage packages [3-5].

Adequate ventilation with fresh air is an effective way to remove $\mathrm{C}_{2} \mathrm{H}_{4}$ from storage rooms. However, this method means an enormous energy and moisture loss and is usually impractical in the case of controlled or modified atmosphere [6]. Another postharvest storage technology is the use of active packaging for ethylene scavenging, including the adsorption and breakdown of ethylene [7]. Sorption is a cheap and relatively simple alternative process. Moreover, the sorbent can be recovered avoiding waste disposal, proving to be a cost-efficient technology in the elimination of a large variety of compounds [8]. Commercial ethylene adsorbents consist of sachets with an active agent impregnated on a porous material. Several materials have been used as ethylene scavengers such as halloysite nanotubes [9], active packaging of low-density polyethylene coated with polylactic acid [10], potassium permanganate supported onto porous inert material with a high surface area such as montmorillonite [11], silica, alumina [12], zeolite, vermiculite, and activated carbon [5], among others, to extend the shelf-life of fresh fruit. Zeolites are aluminosilicates with a negative framework charge that is balanced with alkali or alkaline earth elements and are often used as supporting material. They have a stable structure, a surface area up to $3000 \mathrm{~m}^{2} \mathrm{~g}^{-1}$ and pore radii ranging from $3 \AA$ to $12 \AA$ [5,13]. Moreover, the choice of zeolites for fresh fruit makes them suitable at low or room temperature and high humidity storage conditions [14]. It has been indicated that the removal of $\mathrm{C}_{2} \mathrm{H}_{4}$ can be promoted by the impregnation of an inert support with potassium permanganate $(3.5 \%-12 \%)$ [15], which oxidized ethylene to carbon dioxide $\left(\mathrm{CO}_{2}\right)$ and water $\left(\mathrm{H}_{2} \mathrm{O}\right)$, simultaneously forming manganese dioxide and releasing potassium hydroxide [16]. In addition, several pure metallic elements and metal oxides fixed on supports have been tested as catalysts for the oxidation of ethylene to carbon dioxide and water. According to Terry et al. [17], the ethylene adsorption and removal capacity of palladium (Pd)-impregnated zeolite was far superior to potassium permanganate-based scavengers when used in low amounts at $20^{\circ} \mathrm{C}$ and high relative humidity. Moreover, ethylene removal rate by a palladium chloride $\left(\mathrm{PdCl}_{2}\right)$-impregnated acidified activated carbon scavenger was further promoted by the addition of copper sulfate [18]. Indeed, copper $(\mathrm{Cu})$ has been shown to be helpful in promoting ethylene removal [13]. Additionally, photocatalytic degradation of $\mathrm{C}_{2} \mathrm{H}_{4}$ under UV light irradiation using a mixture of titanium dioxide and silica $\left(\mathrm{TiO}_{2} / \mathrm{SiO}_{2}\right)$ or a nanofiber film containing $\mathrm{TiO}_{2}$ nanoparticles was effective in reducing the concentration of ethylene in the atmosphere surrounding of climacteric fruit, thereby delaying their ripening $[19,20]$. Complete ethylene removal was achieved by a photocatalytic oxidation into carbon dioxide and water [21]. Doping $\mathrm{TiO}_{2}$ with $\mathrm{Cu}^{2+}$ may further improve the photocatalytic activity and minimize deactivation. Besides, the use of zinc oxide $(\mathrm{ZnO})$ as photocatalyst is a suitable alternative to the more expensive $\mathrm{TiO}_{2}$. However, careful attention should be paid in the application of photocatalysis as a process treatment to remove $\mathrm{C}_{2} \mathrm{H}_{4}$. Direct artificial light during the storage of fruit promotes ripening [22]. Hence, photocatalytic treatment should be redesigned and cannot be used directly on fruit as a straightforward technology. The combination of zinc oxide with copper oxide for ethylene scavenging in tomatoes has not been reported. So far, most of these studies mainly concern the characterization of the prepared materials and the application of tests to evaluate fruit maturity and the effect of the ethylene scavenger. However, there is a lack of studies that evidence the chemical interactions among ethylene and the material active sites giving a relationship between such processes with fruit ripening. Therefore, the aim of the present work was to develop a novel copper- and zinc-based ethylene scavenger supported on naturally occurring zeolite and to study the surface interactions among adsorbed molecules and the active sites of the scavenger and their implications on postharvest attributes during the shelf-life of tomatoes. 


\section{Materials and Methods}

\subsection{Materials}

Tomato fruit (Medano cultivar) were purchased from a greenhouse in Pueblo Seco, Nuble, Chile. Natural zeolite, composed of 53\% clinoptilolite, $40 \%$ mordenite, and $7 \%$ quartz with an average grain size of $5.28 \pm 0.28 \mathrm{~mm}$, was provided by the mining company of Minera Formas (Parral, Chile). Argon, oxygen, and carbon dioxide of $99.9 \%$ purity were supplied by Praxair (Santiago, Chile). Ethylene of 99.99\% purity was purchased from Air Liquide S.A. (Houston, TX, USA). Zinc nitrate was obtained from Sigma-Aldrich Corporation (St. Louis, MO, USA), while copper nitrate, ammonium sulfate, copper sulfate, sodium hydroxide, butylated hydroxytoluene, sodium potassium tartrate, ethanol, acetone, and hexane were provided by Merck (Darmstadt, Germany) and were of analytical grade ( $\geq 99.0 \%$ purity). Sodium benzoate and potassium sorbate (food grade) were supplied by Furet (Chillán, Chile). Deionized water $(\geq 18.0 \mathrm{M} \Omega \mathrm{cm})$ was used to prepare solutions using a Thermo Scientific Barnstead Easypure II RF portable ultrapure water system (Waltham, MA, USA).

\subsection{Preparation of Zeolites}

After the grinding and sieving of natural zeolite, a zeolite sample with an average particle size of $0.36 \pm 0.06 \mathrm{~mm}$ was rinsed with deionized water, filtrated and then dried at $105^{\circ} \mathrm{C}$ for $24 \mathrm{~h}$ ( $\mathrm{Z}$ sample). Prior to the treatment of zeolite with copper and zinc cations, zeolite samples $(0.10 \mathrm{w} / \mathrm{v})$ were dispersed in a $0.1 \mathrm{M}$ ammonium sulfate solution and modified by ion-exchange at $90^{\circ} \mathrm{C}$ for $2 \mathrm{~h}$ at a shaking rate of $27 \mathrm{rpm}$. The excess of salt was removed by washing with deionized water during $2 \mathrm{~h}$ at the same conditions as mentioned before. This rinsing procedure was repeated twice for $1 \mathrm{~h}$. The ion-exchange procedure was repeated once again, including the washing step. Afterwards, zeolite samples were thermally degassed in a U-shaped quartz fixed bed furnace at $350{ }^{\circ} \mathrm{C}$ (heating rate of $3{ }^{\circ} \mathrm{C} \mathrm{min}-1$ ) during $2 \mathrm{~h}$ under argon flow $\left(100 \mathrm{~mL} \mathrm{~min}^{-1}\right)$. After this step, pre-treated samples $(0.10 \mathrm{w} / \mathrm{v})$ were dispersed in an aqueous solution of both copper and zinc nitrate $(66.4 \mathrm{mM})$ and modified by metal ion-exchange for $24 \mathrm{~h}$ at $90^{\circ} \mathrm{C}$ under shaking at $27 \mathrm{rpm}$ to prepare the modified zeolite doped with copper and zinc cations. After repeating the rinsing and degassing procedures, samples were stored in a desiccator before use. Prior to the adsorption experiments, samples were heated under oxygen flow $\left(100 \mathrm{~mL} \mathrm{~min}{ }^{-1}\right.$ ) at $350{ }^{\circ} \mathrm{C}$ (with a heating rate of $1{ }^{\circ} \mathrm{C} \mathrm{min}^{-1}$ ) for $4 \mathrm{~h}$ before quenching to room temperature. The physical and chemical surface properties of natural ( $Z$ sample) and modified natural zeolite ( $\mathrm{Z}-\mathrm{Cu} / \mathrm{Zn}$ sample) used in this study have been recently published by Abreu et al. [23] (Table 1).

Table 1. Physical and chemical characteristics of natural and modified zeolite samples ${ }^{1}$ [23].

\begin{tabular}{|c|c|c|c|c|c|c|c|c|c|c|c|c|c|c|c|c|c|}
\hline Sample & $\begin{array}{c}\mathrm{S}_{\mathrm{BET}} \\
{\left[\mathrm{m}^{2} \mathrm{~g}^{-1}\right]}\end{array}$ & $\begin{array}{c}V_{\text {meso }} \\
{\left[\mathrm{cm}^{3} \mathrm{~g}^{-1}\right]}\end{array}$ & $\begin{array}{c}V_{\text {micro }} \\
{\left[\mathrm{cm}^{3} \mathrm{~g}^{-1}\right]}\end{array}$ & $\begin{array}{c}\mathrm{Si} \\
{[\%]}\end{array}$ & $\begin{array}{c}\mathrm{Al} \\
{[\%]}\end{array}$ & $\begin{array}{l}\mathrm{Ca} \\
{[\%]}\end{array}$ & $\begin{array}{l}\mathrm{Fe} \\
{[\%]}\end{array}$ & $\begin{array}{l}\mathrm{Na} \\
{[\%]}\end{array}$ & $\begin{array}{c}\mathbf{K} \\
{[\%]}\end{array}$ & $\begin{array}{c}\mathrm{Ti} \\
{[\%]}\end{array}$ & $\begin{array}{l}\mathrm{Mg} \\
{[\%]}\end{array}$ & $\begin{array}{l}\mathrm{Mn} \\
{[\%]}\end{array}$ & $\begin{array}{l}\mathrm{Sr} \\
{[\%]}\end{array}$ & $\begin{array}{c}\mathrm{S} \\
{[\%]}\end{array}$ & $\begin{array}{l}\mathrm{Zr} \\
{[\%]}\end{array}$ & $\begin{array}{l}\mathrm{Zn} \\
{[\%]}\end{array}$ & $\begin{array}{l}\mathrm{Cu} \\
{[\%]}\end{array}$ \\
\hline Z & 281 & 0.14 & 0.07 & 65.4 & 12.3 & 11.1 & 5.3 & 2.1 & 1.9 & 0.9 & 0.5 & 0.1 & 0.1 & 0.1 & 0.1 & 0.0 & - \\
\hline $\mathrm{Z}-\mathrm{Cu} / \mathrm{Zn}$ & 337 & 0.10 & 0.11 & 68.3 & 13.2 & 4.1 & 4.7 & - & 0.9 & 0.8 & 0.2 & 0.1 & 0.1 & 0.1 & 0.1 & 3.3 & 4.3 \\
\hline
\end{tabular}

\subsection{Characterization of Zeolites}

\subsubsection{DRIFTS Operando Study}

Interactions among ethylene molecules and zeolite surface, in the presence of air humidity, were studied by diffuse reflectance infrared Fourier transform spectroscopy (DRIFTS) in operando mode (see Figure 1). Experiments were performed using a JASCO FT/IR 4700 spectrometer provided by JASCO International Co., Ltd. (Tokyo, Japan) equipped with a mercury cadmium telluride detector (MCTD). Zeolite sample ( $0.08 \mathrm{~g}$ ) was loaded in a Praying Mantis diffuse reflectance cell supplied by Harrick Scientific Products Inc. (New York, NY, USA). Then, a pure ethylene stream was continuously sent to 
the diffuse reflectance cell operating at $20^{\circ} \mathrm{C}$ and spectra were registered every $1 \mathrm{~min}$, from $4000 \mathrm{~cm}^{-1}$ to $400 \mathrm{~cm}^{-1}$ with an optical resolution of $1 \mathrm{~cm}^{-1}$.

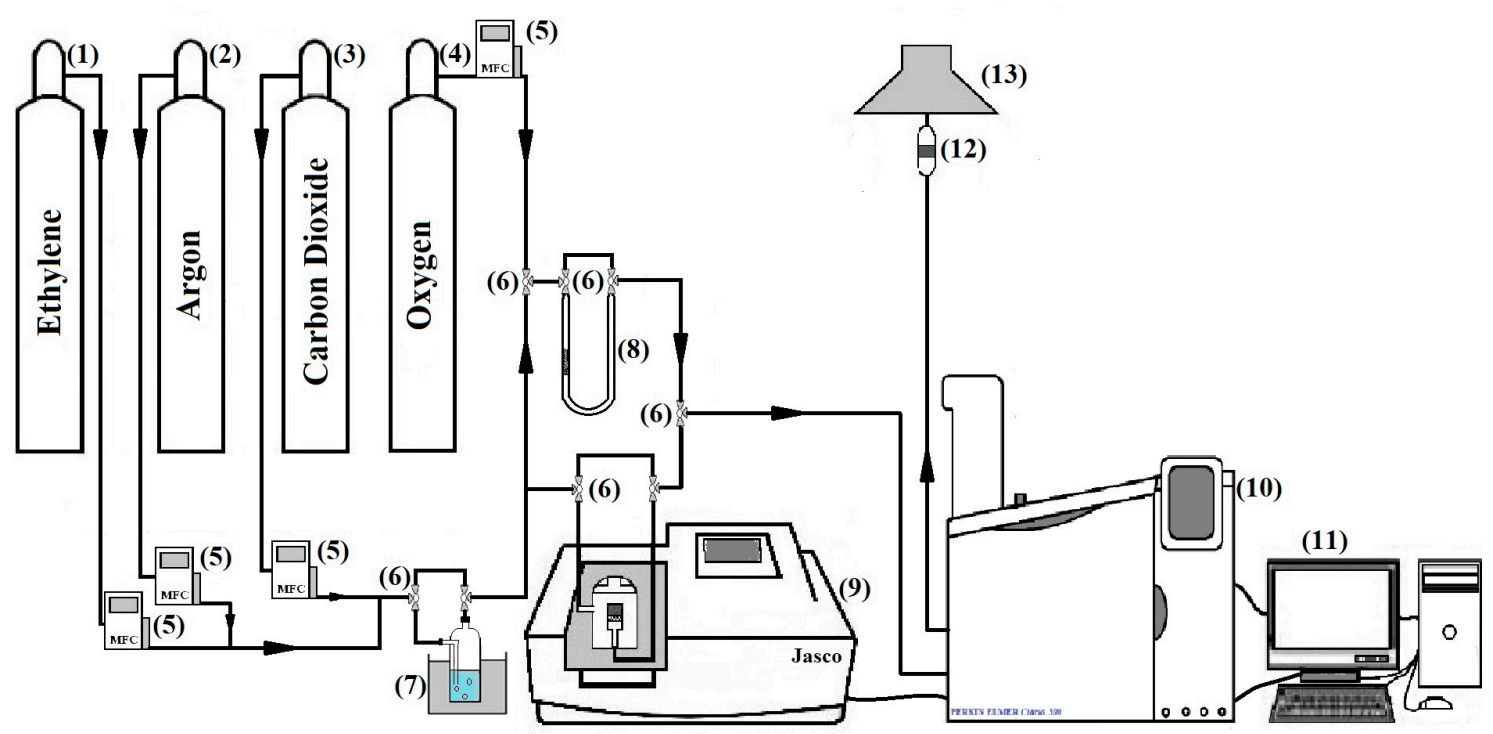

Figure 1. General experimental setup used to study surface interactions among ethylene and zeolite by diffuse reflectance infrared Fourier transform spectroscopy (DRIFTS) in operando mode and the retention of ethylene and carbon dioxide using a quartz U-shaped fixed bed adsorber at room temperature: (1) ethylene cylinder, (2) argon cylinder, (3) carbon dioxide cylinder, (4) oxygen cylinder, (5) mass flow controller, (6) three way valve, (7) water saturator, (8) U-type fixed bed adsorber, (9) Praying Mantis diffuse reflectance cell set in a JASCO Fourier transform infrared spectroscopy (FT/IR 4700) spectrometer, (10) Perkin Elmer Clarus 500 gas chromatograph, (11) computer, (12) $\mathrm{KMnO}_{2}$ trap, and (13) extractor hood.

\subsubsection{Breakthrough and Regeneration Experiments}

To further evaluate the influence of natural and copper- and zinc-modified zeolites toward ethylene and carbon dioxide retention, breakthrough adsorption experiments of ethylene or carbon dioxide were performed in two identical quartz U-shaped fixed bed columns manually packed at atmospheric pressure and $20^{\circ} \mathrm{C}$ with $0.30 \mathrm{~g}$ of natural zeolite and zeolite doped with copper and zinc cations, respectively (see Figure 1). Before breakthrough adsorption experiments, samples were heated with an oxygen flow $\left(100 \mathrm{~mL} \mathrm{~min}^{-1}\right.$, heating rate of $\left.1{ }^{\circ} \mathrm{C} \mathrm{min}^{-1}\right)$ for $4 \mathrm{~h}$, reaching a final temperature of $350{ }^{\circ} \mathrm{C}$ and then cooling to room temperature. Inlet concentration of ethylene was fixed at $120 \mu \mathrm{g} \mathrm{L}^{-1}$ and at $1500 \mu \mathrm{g} \mathrm{L}^{-1}$ for carbon dioxide by diluting each pure gas with a flow of argon. When starting the breakthrough experiment, ethylene was continuously introduced to the zeolite fixed bed at a flow rate of $25 \mathrm{~mL} \mathrm{~min}^{-1}$ at $20^{\circ} \mathrm{C}$, while the outlet gas from the column was analyzed on-line by gas chromatography using a Perkin Elmer Clarus 500 gas chromatograph (Shelton, CT, USA) as a function of time, whereby adimensional concentration $\left(C_{i, t} / C_{i, 0}\right)$ was expressed as a function of treated bed volumes ( $\mathrm{L}_{\text {gas }} \mathrm{L}^{-1}$ adsorbent). Similarly, in the case of the breakthrough adsorption experiments of carbon dioxide, it was introduced to the zeolite columns at a flow rate of $300 \mathrm{~mL} \mathrm{~min}^{-1}$ monitoring the outlet concentration on-line by gas chromatography using a Perkin Elmer Clarus 500 chromatograph (Shelton, CT, USA), as indicated previously [24]. Breakthrough experiments were stopped when zeolite samples reached saturation. Adsorbed quantity of component $i$ was calculated by integration of the area from the breakthrough curve according to the following equation:

$$
q_{i}=\frac{F C_{i, i n}}{m} \int_{0}^{t_{\mathrm{s}}}\left(1-\frac{C_{i, t}}{C_{i, i n}}\right) d t
$$


where $q_{i}$ is the adsorbed amount of component $i$ ( $\mu \mathrm{g} i \mathrm{~g}^{-1}$ adsorbent), $F$ is the flow rate of feed $\left(\mathrm{L} \mathrm{min}^{-1}\right)$, $m$ is the mass of adsorbent $(\mathrm{g}), C_{i, \text { in }}$ is the inlet concentration of component $i\left(\mu \mathrm{g} \mathrm{L}^{-1}\right), C_{i, t}$ is the outlet concentration of component $i\left(\mu \mathrm{g} \mathrm{L}^{-1}\right)$ at specific adsorption time $t$, and $t_{s}$ is the time to reach the saturation of the adsorbent with component $i$ (min).

After reaching saturation, zeolite samples were submitted to temperature-programmed regeneration experiments in order to gain information about the strength of adsorption of ethylene and carbon dioxide to zeolite active sites. Zeolite samples were heated under argon flow $\left(45 \mathrm{~mL} \mathrm{~min}{ }^{-1}\right)$ from $30{ }^{\circ} \mathrm{C}$ to $550{ }^{\circ} \mathrm{C}$ (heating rate of $3{ }^{\circ} \mathrm{C} \mathrm{min}^{-1}$ ) and the concentration of ethylene or carbon dioxide in the outlet gas was analyzed by gas chromatography, following the same procedures as explained previously.

\subsection{Postharvest Treatments}

Tomato fruit, Solanum lycopersicum, were harvested at breaker stage in December 2017 and immediately transported to the postharvest laboratory of Universidad de Concepción. Tomatoes were sorted for uniformity according to size and color. Fruit were dipped for $15 \mathrm{~min} \mathrm{in} 0.1 \%(\mathrm{w} / \mathrm{v})$ potassium sorbate and $0.1 \%(\mathrm{w} / \mathrm{v})$ sodium benzoate solution. After drainage, tomatoes were washed with sterile deionized water and air-dried in a laminar flow hood at room temperature for $1 \mathrm{~h}$, followed by storage in the dark at $10^{\circ} \mathrm{C}$ for $12 \mathrm{~h}$.

Fruit were separated into three groups, and each group consisted of three lots. For each determination, two replicates (r) per treatment and sampling period were used. The first group consisted of tomatoes stored without ethylene sorbent material (control), the second group of fruit stored with $10 \mathrm{~g}$ natural zeolite $(Z)$ per container, and the third group comprised tomatoes with $10 \mathrm{~g}$ zeolite doped with copper and zinc $(\mathrm{Z}-\mathrm{Cu} / \mathrm{Zn})$ per container. Tomatoes (approximately $0.75 \mathrm{~kg}$ per experimental unit) were stored in hermetically sealed glass desiccators $(10 \mathrm{~L})$ at $20^{\circ} \mathrm{C}$ in the dark and a constant relative humidity $(\mathrm{RH})$ of $88 \%$ provided by a saturated solution of sodium benzoate $\left(\mathrm{C}_{6} \mathrm{H}_{5} \mathrm{OONa}\right)$. Zeolite samples were deposited on glass fiber within a stainless-steel basket hanging in the center of each desiccator (see Figure 2). Quality fruit parameters (size, weight, skin color, texture characteristics, titratable acidity, soluble solids, moisture content, and reducing sugars and lycopene content) were analyzed at the beginning of the experiment, and after $8 \mathrm{~d}$ and $15 \mathrm{~d}$ in accordance with tomatoes shelf-life and preliminary experiments.



Figure 2. Schematic experimental setup for tomato storage over time for different treatments. 


\subsection{Gas Composition in the Atmosphere of Tomato Containers}

Concentrations of $\mathrm{C}_{2} \mathrm{H}_{4}$ and $\mathrm{CO}_{2}, \mathrm{O}_{2}$, and $\mathrm{N}_{2}$ were determined during the whole storage time of tomato fruit. Samples were daily taken from the headspace atmospheres of each desiccator and analyzed by gas chromatography using a Perkin Elmer Clarus 500 chromatograph (Shelton, CT, USA) equipped with a sample injector operated at $200{ }^{\circ} \mathrm{C}$ and featuring two parallel connected columns, a flame ionization detector (FID) operating at $250{ }^{\circ} \mathrm{C}$ for $\mathrm{C}_{2} \mathrm{H}_{4}$ detection and a thermal conductivity detector (TCD) operating at $200{ }^{\circ} \mathrm{C}$ for $\mathrm{CO}_{2}, \mathrm{O}_{2}$, and $\mathrm{N}_{2}$ determination. A sample of $2.5 \mathrm{~mL}$ of the headspace atmosphere from each desiccator was withdrawn using a syringe and injected into the gas chromatograph. A flow of $7 \mathrm{~mL} \mathrm{~min}^{-1}$ of helium was used as a carrier gas for ethylene determination, using a capillary column (VOCOL ${ }^{\mathrm{TM}}, 60 \mathrm{~m}$ length $\times 0.53 \mathrm{~mm}$ i.d., with $3.0 \mu \mathrm{m}$ film thickness) coupled to the FID detector. Separations started at an initial oven temperature of $40{ }^{\circ} \mathrm{C}$; then temperature increased to $170{ }^{\circ} \mathrm{C}$ at $2{ }^{\circ} \mathrm{C} / \mathrm{min}^{-1}$ and held at $170{ }^{\circ} \mathrm{C}$ for $5 \mathrm{~min}$. After each separation, elution proceeded for further $2 \mathrm{~min}$ before cooling down the oven and to stabilize the column for the next run. Carbon dioxide, oxygen and nitrogen were analyzed by injecting $1 \mathrm{~mL}$ of the headspace atmosphere of each desiccator into the gas chromatograph. Separation was conducted using a packed column $(4.5 \mathrm{~m}$ length $\times 2.1 \mathrm{~mm}$ i.d., containing 60/80 mesh Carboxen-1000 packing) coupled to TCD, applying $30 \mathrm{~mL}$ helium $\mathrm{min}^{-1}$. The temperature program was started at $40^{\circ} \mathrm{C}$ and increased to $170{ }^{\circ} \mathrm{C}$ at $4{ }^{\circ} \mathrm{C} / \mathrm{min}^{-1}$ with a holding time of 6 min.

\subsection{Determination of Physical and Chemical Properties of Tomato Fruit}

Equatorial and polar diameters of individual fruit were measured with a digital vernier caliper $(150 \times 0.02 \mathrm{~mm}$; Stanford professional). Weight of each fruit lot was recorded using an analytical balance (Shimadzu BL-320H, Kyoto, Japan) with $0.001 \mathrm{~g}$ precision. Weight loss was expressed as percentage loss of the original weight using the same samples $(n=3)$ at each sampling time throughout the experiment [25]. Skin color was measured in triplicate at three different points in the equatorial area of fruit using the CIE L ${ }^{*} a^{*} b^{*}$ color space of a HunterLab colorimeter Color Quest II (Hunter Associates Laboratory, Reston, VA, USA). Hue angle $\left(h_{a b}\right)$ was quantified by $h_{a b}=\operatorname{arctangent}\left(b^{*} / a^{*}\right)$, where green $=180^{\circ}$, yellow $=90^{\circ}$ and red $=0^{\circ}$. Texture characteristics of tomato samples were measured using the Instron Universal Testing Machine (ID 4467 H 1998, Instron Co., Norwood, MA, USA) by force-deformation measurements, using the compression test for food materials of convex shape [26]. Stylar, equatorial and calyx regions were marked on the fruit. The compression test on each fruit involved six measurements, that is, two determinations in each region using a cylindrical stainless-steel plunger $(3.21 \mathrm{~mm})$ and a crosshead speed of $20 \mathrm{~mm} \mathrm{~min}^{-1}$ [27]. Bioyield or critical force $\left(\mathrm{F}_{\text {crit }}\right)$ and apparent modulus of elasticity (E) were calculated according to ASAE S368.2 standards [26], using a Poisson's ratio of 0.45 [28].

Then, each fruit was liquefied in a commercial Oster 4172-051 blender (México City, México), and titratable acidity, soluble solids, and moisture contents were determined. Moisture content of tomato pulp samples was determined by gravimetric method. About $20 \mathrm{~g}$ of samples were dried on Petri dishes in a Binder BL-320H oven (Tuttlingen, Germany) at $70^{\circ} \mathrm{C}$ until constant weight. Moisture content was expressed as percentage of loss of initial weight (WL) (wet basis). Soluble solids (SS) content was measured with a BOECO 32,195 digital refractometer (Hamburg, Germany), expressed as percentage of sucrose equivalent. Titratable acidity (TA) was determined by titration with $0.1 \mathrm{~N} \mathrm{NaOH}$ and expressed as percentage of citric acid equivalent [29]. Reducing sugars (RS) were determined by the Layne and Eynon method based on the reduction of $\mathrm{Cu}^{2+}$-complex with tartaric acid in alkaline solutions [30]. The parameter was expressed as percentage of invert sugar weight/fresh sample weight. The maturity index (MI) was expressed as the ratio between reducing sugars and titratable acidity. Lycopene content was determined according to the method proposed by Fish et al. [31] with minor modifications. Approximately $0.6 \mathrm{~g}$ of homogenized tomato sample was introduced into a $50 \mathrm{~mL}$ amber screw-top vial containing $5 \mathrm{~mL}$ acetone with $0.05 \%(\mathrm{w} / \mathrm{v})$ butylated hydroxytoluene, $5 \mathrm{~mL} 95 \%(\mathrm{v} / \mathrm{v})$ ethanol and $10 \mathrm{~mL}$ hexane. All solvents were refrigerated previously at $4{ }^{\circ} \mathrm{C}$ and stored on ice before 
use. Sample was stirred at $1500 \mathrm{rpm}$ for $10 \mathrm{~min}$ using a VM-3000 mini-vortexer (Thorofare, NJ, USA). After shaking, $3 \mathrm{~mL}$ of distilled water were added to the vial and sample was shaken for additional $5 \mathrm{~min}$. Then, vial was left at $4{ }^{\circ} \mathrm{C}$ in the dark for $30 \mathrm{~min}$ to allow for phase separation. Absorbance of the hexane layer was measured at $503 \mathrm{~nm}$ versus a blank of hexane using a Merck UV-visible spectrophotometer Pharo 300 Spectroquant $₫(D a r m s t a d t$, Germany) and results were expressed as mg lycopene per $\mathrm{kg}$ dry weight of tomato. All measurements were assayed in triplicate.

\subsection{Statistical Analysis}

Analysis of variance (ANOVA) at $\mathrm{P}=0.05$ was performed to assess statistically significant differences among treatments for tomato quality attributes by applying Duncan's multiple range test using Statgraphics (C) Centurion XVI, version 16.1 .15 provided by Statpoint Technologies (Warrington, VA, USA).

\section{Results and Discussion}

\subsection{Ethylene Concentration in the Atmosphere of Tomatoes Containers}

Ethylene concentration diminished by $37 \%$ for natural zeolite and $57 \%$ for modified zeolite after $8 \mathrm{~d}$ of storage, followed by an increase of ethylene concentrations reaching a plateau value of about $40 \mu \mathrm{g} \mathrm{L}^{-1}$ after $10 \mathrm{~d}$ for all treatments, and apparently associated to the saturation of active sorption sites (Figure 3). A comparison of the ethylene removal efficiency using natural and modified natural zeolite doped with copper and zinc to some other ethylene scrubbers reported in the literature is presented in Table 2. As can be seen, the obtained result using modified natural zeolite doped with copper and zinc is within the range of values reported using different scrubbers for ethylene removal for different horticultural products. Control treatment showed just one pronounced increase of ethylene concentration at $2.5 \mathrm{~d}$ of tomato storage, while a second increase appeared at $9.5 \mathrm{~d}$ for zeolite treatments (Figure 3). A maximum ethylene concentration for control was obtained of about $43.8 \pm 8.2 \mu \mathrm{g} \mathrm{L}^{-1}$ per $\mathrm{kg}$ of tomato. In particular, the ion-exchange of zeolite with copper and zinc cations increased the capacity to remove ethylene from an environment with $88 \% \mathrm{RH}$ and $15 \%(\mathrm{v} / \mathrm{v}) \mathrm{O}_{2}$ during the first week of tomato storage. More efficient ethylene scrubbing promotes ethylene gradient formation and, thus, diffusion across the tomato skin and flesh barriers, diminishing the internal ethylene concentration and retarding the main ethylene burst for about seven days. However, autocatalytic ethylene synthesis may result finally in a sharp increase of the internal $\mathrm{C}_{2} \mathrm{H}_{4}$ concentration that can exceed $100 \mathrm{ppm}$ [2]. This may be the consequence of unsteady state conditions between an accelerated ethylene production and a relatively low ethylene adsorption rate due to mass transfer limitations.

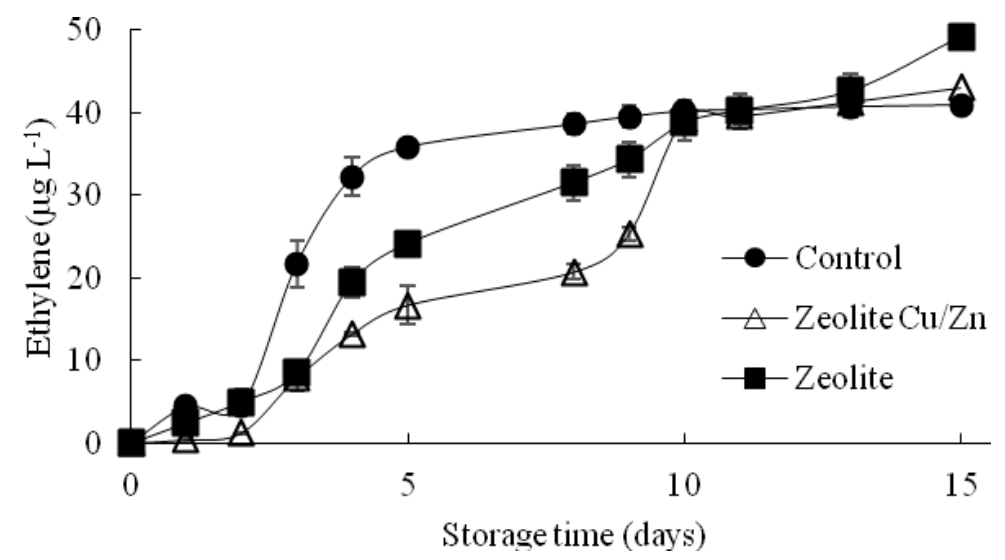

Figure 3. Ethylene concentration for tomato storage over time for different treatments. 
Table 2. Comparison of the removal of ethylene using natural $(Z)$ and modified natural zeolite doped with copper and zinc $(\mathrm{Z}-\mathrm{Cu} / \mathrm{Zn})$ to some other ethylene scrubbers reported in the literature.

\begin{tabular}{|c|c|c|c|}
\hline Ethylene scrubbers & Removal (\%) & Horticultural Products & References \\
\hline Z & 37 & Tomato & This work \\
\hline $\mathrm{Z}-\mathrm{Cu} / \mathrm{Zn}$ & 57 & Tomato & This work \\
\hline $\begin{array}{l}\text { Potassium permanganate loaded } \\
\text { on protonated montmorillonite }\end{array}$ & 79 & Blueberry & [11] \\
\hline Palladium activated carbon & 65 & Tomato & [13] \\
\hline Pd-impregnated zeolite & 100 & Banana, avocado, strawberry & [17] \\
\hline $\begin{array}{l}\text { Acidified activated carbon } \\
\text { powder impregnated with } \\
\mathrm{PdCl}_{2} \text { and } \mathrm{CuSO}_{4}\end{array}$ & 80 & Broccoli & [18] \\
\hline $\begin{array}{l}\text { Nanofibers containing } \mathrm{TiO}_{2} \\
\text { nanoparticles }\end{array}$ & 45 & Banana & [20] \\
\hline Titanium dioxide coated glass & 66 & Apple & [21] \\
\hline $\begin{array}{l}\text { Granular-activated carbon } \\
\text { impregnated with palladium }\end{array}$ & 56 & Tomato & [32] \\
\hline
\end{tabular}

Although $\mathrm{C}_{2} \mathrm{H}_{4}$-scavenging was not very successful at the end of the storage period, probably due to an insufficient adsorption capacity of zeolites at high relative humidity, ethylene removal might be improved by increasing the amount of copper and zinc combined with ultraviolet irradiation, using the modified zeolites as photocatalytic material to promote ethylene degradation and to free the active adsorption sites on the zeolite surface.

\subsection{Interaction between Ethylene and Zeolites}

Figure 4 displays the evolution of DRIFTS spectra as a function of time for samples of natural zeolite (4a) and modified natural zeolite doped with copper and zinc (4b) continuously exposed to a stream of pure moistened ethylene. According to Figure 4A,B, the intensity in $\mathrm{OH}$ vibrating bands such as Si-OH-Al bridge groups $\left(3590 \mathrm{~cm}^{-1}\right)$ and external $\mathrm{Si}-\mathrm{OH}$ groups $\left(3745 \mathrm{~cm}^{-1}\right)$ decreased as zeolites were exposed to ethylene. In the case of modified zeolite (Figure 4B), the interactions with $\mathrm{Si}-\mathrm{OH}-\mathrm{Al}$ groups $\left(3590 \mathrm{~cm}^{-1}\right.$ ) are greater than in natural zeolite (Figure $\left.4 \mathrm{~A}\right)$. Such findings are related to the formation of new Brønsted active sites during the modification process that increases ethylene adsorption. Our results confirm that the adsorption mechanism takes place by the interaction of ethylene molecules with Brønsted active sites present at the zeolite surface. Moreover, DRIFTS analysis to the modified zeolite sample suggests that ethylene molecules interact not only with Brønsted active sites but also with metal cations incorporated in the zeolite surface. Lower intensity can be clearly observed in the bands located at $3590 \mathrm{~cm}^{-1}$ (Si-OH-Al bridge groups) in the modified zeolite sample as the contact time elapsed. Such results are in agreement with those presented in Figure 3, since ethylene concentration remains lower in the gas headspace of stored tomatoes when modified zeolite is used. Ethylene molecules seem to be adsorbed at the new active sites generated in the zeolite after the applied modification treatments. The IR bands registered at $2835 \mathrm{~cm}^{-1}, 2807 \mathrm{~cm}^{-1}$, and $2820 \mathrm{~cm}^{-1}$ related to $\mathrm{C}-\mathrm{H}$ stretching vibrations in that sample have been associated to the interaction of metals introduced in the zeolite surface with ethylene molecules. These IR bands could be attributed to modifications in the symmetry of ethylene molecules due to the interactions of cations with $\pi$-electrons of ethylene molecules. Meanwhile, after some minutes of contact time, other characteristic bands of gas phase ethylene appear in the range around $950 \mathrm{~cm}^{-1}, 1420 \mathrm{~cm}^{-1}, 1700-1900 \mathrm{~cm}^{-1}$, and $2970-3125 \mathrm{~cm}^{-1}$, suggesting the saturation of the surface. Additionally, water adsorption on the zeolite surface can be observed by the increase of the band located at $1635 \mathrm{~cm}^{-1}$ and a broad band between $3200 \mathrm{~cm}^{-1}$ and $3400 \mathrm{~cm}^{-1}$ as contact time increased, having higher intensities in the case of the natural zeolite sample. 

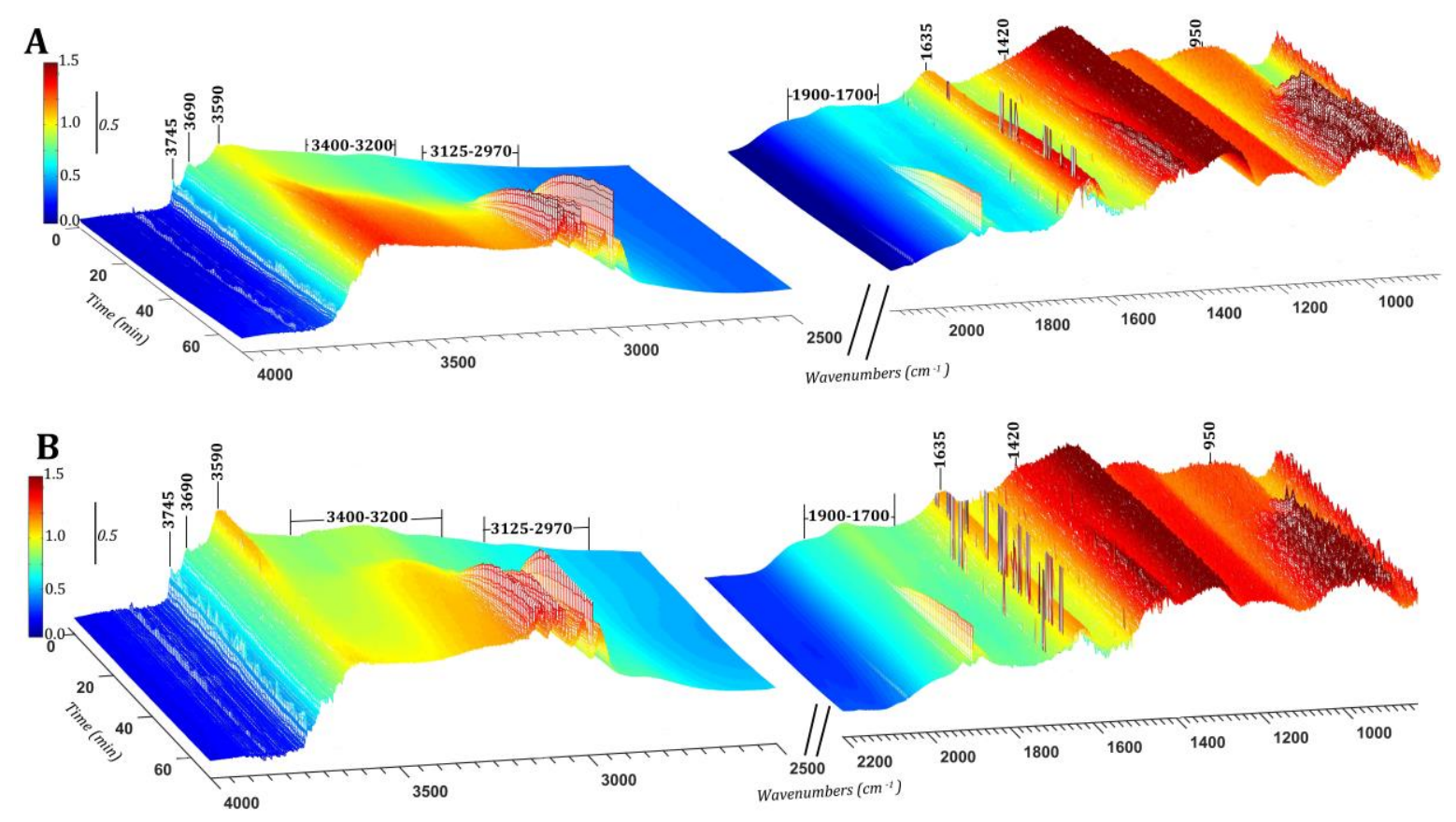

Figure 4. DRIFTS operando spectra of ethylene adsorption onto natural and modified natural zeolite samples in the presence of humidity. (A) Natural zeolite; (B) zeolite modified with copper and zinc.

However, high moisture conditions might also affect negatively the adsorption capacity of the modified zeolite, particularly at the end of tomato storage. It has been indicated that both water and oxygen reduced the adsorption capacity of zeolite, while the greatest removal of $\mathrm{C}_{2} \mathrm{H}_{4}$ occurs in the presence of nitrogen [14]. In the absence of water and oxygen, ethylene is converted to ethylidyne $\left(\mathrm{CCH}_{3}\right)$ species, whereby carbon forms three bonds to surface metal atoms. In contrast, the presence of adsorbed oxygen favored $\pi$-bonded ethylene over di- $\sigma$ bonded ethylene adsorption [14]. The adsorption process in the case of natural zeolite has been indicated to take place mainly by weak hydrogen bonding interactions among $\mathrm{CH}$ atoms of ethylene and $\mathrm{O}$ atoms of terminal $\mathrm{Si}-\mathrm{OH}$ and Si-OH-Al bridges of zeolite [23,33]. In the presence of moisture, water and ethylene molecules compete for the same active adsorption sites of zeolites [23] as the $\mathrm{CH}-\mathrm{O}$ interactions for ethylene are weaker than the $\mathrm{OH}-\mathrm{O}$ interactions between water and zeolite [34]. As a result, water gets involved in the adsorption mechanism blocking ethylene interactions and diminishing considerably the ethylene adsorption at the final stage of tomato storage.

\subsection{Breakthrough and Zeolite Regeneration}

According to Figure 5 a, ethylene was retained until $75 \times 10^{3}$ bed volume (BV) by modified zeolite with a saturation of sorption material after $140 \times 10^{3} \mathrm{BV}$ and a higher adsorbed amount of ethylene on modified zeolite $\left(4683 \mu \mathrm{g} \mathrm{g}^{-1}\right)$ compared to natural zeolite $\left(4263 \mu \mathrm{g} \mathrm{g}^{-1}\right)$. Thus, the incorporation of copper and zinc cations in zeolite favored ethylene adsorption. At the same time, the ion-exchange of natural zeolite with copper and zinc cations diminished the retention of carbon dioxide, decreasing the adsorbed amount of $\mathrm{CO}_{2}$ from $52.5 \mathrm{mg} \mathrm{g}^{-1}$ for natural zeolite to $31.7 \mathrm{mg} \mathrm{g}^{-1}$ for modified zeolite (Figure 5b). As shown in Table 1, compensating cations of basic nature originally present at natural zeolite surface were removed. These results indicate that the applied sequential modification treatment produced a modified zeolite that is less susceptible to $\mathrm{CO}_{2}$ adsorption. 
a)
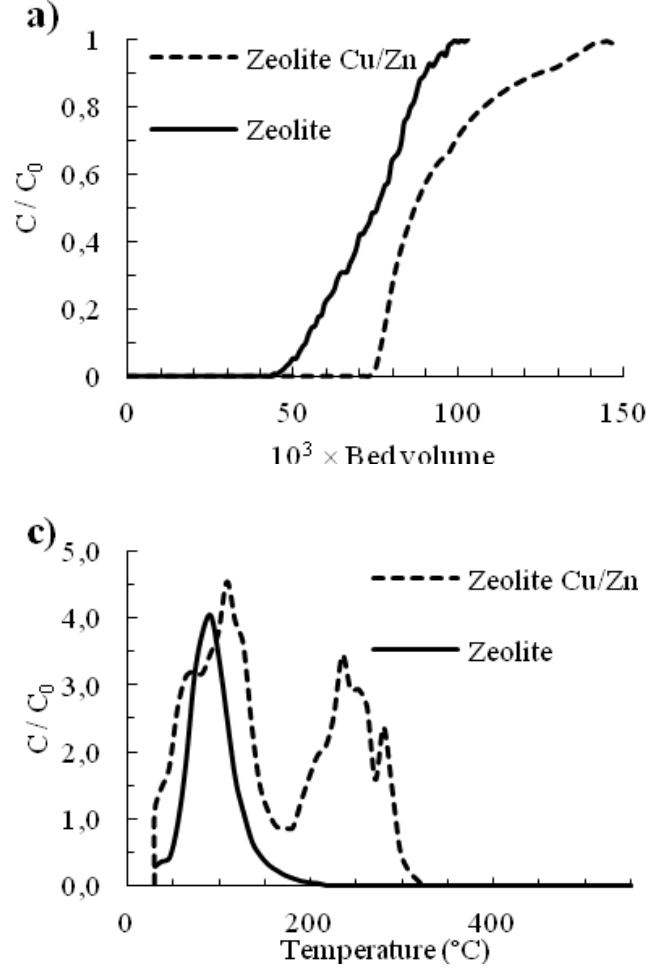

b)

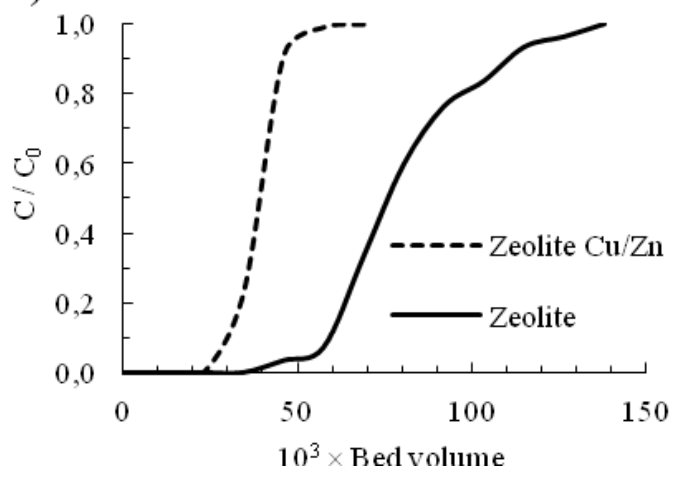

d)

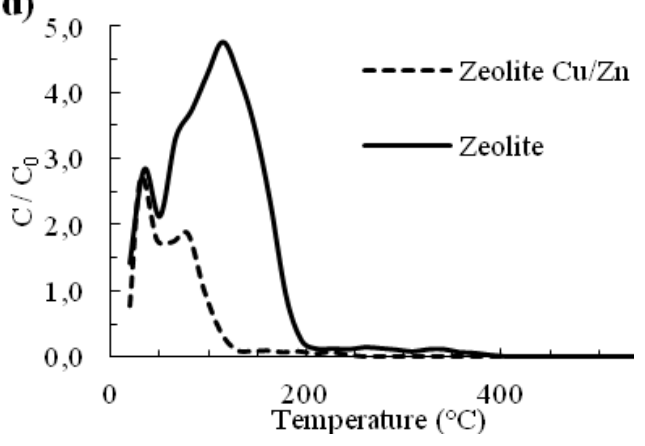

Figure 5. Experimental breakthrough curves for ethylene (a) and carbon dioxide (b) and desorption curves for ethylene (c) and carbon dioxide (d) on natural zeolite and modified zeolite with copper and zinc.

On the other hand, desorption of ethylene from natural zeolite took place at relatively low temperature (Figure $5 c$ ), which indicates weak interactions between adsorbate and adsorbent, probably due to hydrogen bonds among ethylene molecules and $\mathrm{OH}$ groups of the zeolite framework. In the case of modified zeolite (Figure 5c), ethylene evolved as two main desorption peaks that can be related to different adsorption strength among ethylene molecules and active sites of the zeolite surface. The thermal desorption of ethylene detected at low temperature $\left(30-150^{\circ} \mathrm{C}\right)$ means weak interactions between adsorbate and adsorbent, while the desorption of ethylene at high temperature $\left(170-300{ }^{\circ} \mathrm{C}\right)$ suggests stronger chemical interactions that probably involve the copper and zinc compensation cations incorporated in the zeolite surface. According to the desorption profile of carbon dioxide, natural zeolite had a higher adsorption capacity toward $\mathrm{CO}_{2}$ compared to modified zeolite (Figure $5 \mathrm{~d}$ ). This behavior could be related to strong electrostatic interactions of $\mathrm{CO}_{2}$ quadrupoles with vacant zeolitic cations of basic character present at the surface of natural zeolite [35]. Moreover, these desorption data suggest a higher amount of basic surface sites in the natural zeolite compared to the modified sample [36]. A great part of these basic sites were initially present in the natural zeolite as compensating cations and were removed during the first step of the applied modification process using ammonium sulfate followed by thermal degasification at $350^{\circ} \mathrm{C}$, having an impact in the increase of microporous surface area and microporous volume [23].

Moreover, the incorporation of $\mathrm{Cu}^{2+}$ and $\mathrm{Zn}^{2+}$ ions after the ion-exchange treatments into the zeolite structure also contributes to the decrease in the content of compensating cations (Table 1). This generates additional, ion-induced dipole interactions between the ethylene molecules and the new compensating cations located on the zeolite surface. It also improves ethylene binding via the interaction among the $\pi$-electrons of ethylene and the orbitals of compensating cations within the zeolite framework [34]. 


\subsection{Carbon Dioxide Concentration in the Atmosphere of Tomatoes Containers}

During the experiments, $\mathrm{CO}_{2}$ levels in the atmosphere of glass desiccators increased continuously during the storage of control tomatoes with a more pronounced increase of $\mathrm{CO}_{2}$ at the beginning, yielding a maximum $\mathrm{CO}_{2}$ concentration of about $300 \mathrm{mg} \mathrm{L}^{-1}$ at day 10.5 (Figure 6). However, the $\mathrm{CO}_{2}$ profile is more complex in the presence of zeolites because of the combination of tomato respiration, and $\mathrm{CO}_{2}$ adsorption and desorption phenomena. First, a strong increase of $\mathrm{CO}_{2}$ concentrations was observed at day 0.5 , which may be due to the accommodation of our system, whereby water vapor in the headspace would promote $\mathrm{CO}_{2}$ desorption. The zeolites used here having an atomic ratio of silica to alumina of roughly five, are substantially hydrophilic with a water adsorption capacity much higher than the one for $\mathrm{CO}_{2}$ [37]. In addition, carbon dioxide production has been delayed during the first six days in the presence of modified zeolite. This adsorbent is able to shift the $\mathrm{CO}_{2}$ increase for six days compared to control treatment due to the presence of copper and zinc (Figure 6). However, carbon dioxide concentrations increased strongly to approximately $585 \mathrm{mg} \mathrm{L}^{-1}$ after $14 \mathrm{~d}$ of storage at $20{ }^{\circ} \mathrm{C}$, which exceeds the recommended range of $\mathrm{CO}_{2}$ for tomatoes of $2 \%-5 \%(\mathrm{v} / \mathrm{v})$. High levels of $\mathrm{CO}_{2}$ reduce the sensitivity to ethylene and inhibit ethylene action in tomatoes [6].

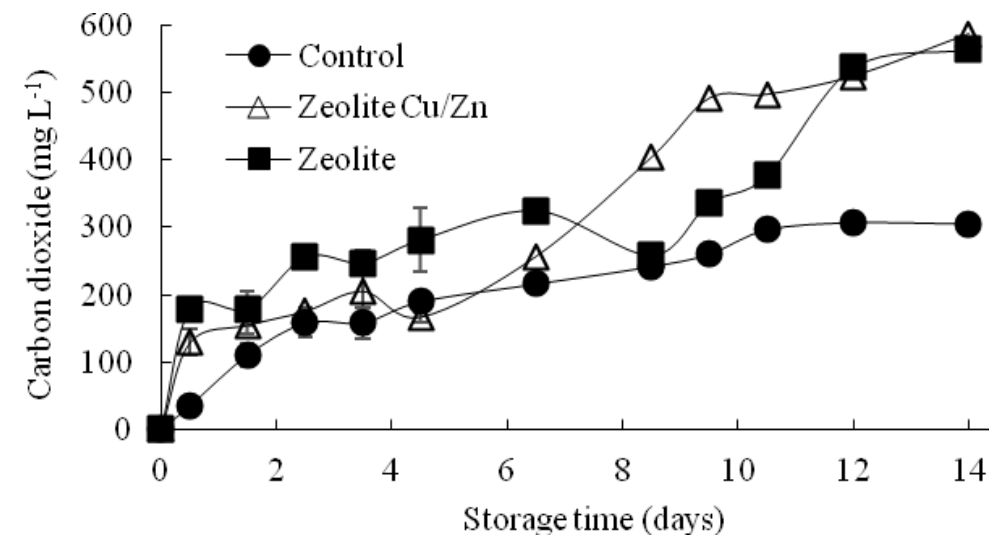

Figure 6. Carbon dioxide concentration as a function of storage time for different treatments.

\subsection{Effect of Zeolites on Tomato Quality}

Excessive loss of moisture in fresh fruit results in a considerable weight reduction with a negative impact on fruit quality, as it is generally associated with loss of freshness. In this study, no significant effect of sorbents on weight loss of postharvest tomatoes was found although $\mathrm{CO}_{2}$ production was retarded for $6 \mathrm{~d}$ of tomato storage in the presence of modified zeolite (Table 3).

Table 3. Physicochemical and ripening indices of tomatoes stored at $20^{\circ} \mathrm{C}$ without (control), in the presence of zeolite $(\mathrm{Z})$ or modified zeolite $(\mathrm{Z}-\mathrm{Cu} / \mathrm{Zn})^{1}$.

\begin{tabular}{|c|c|c|c|c|c|c|c|c|c|c|c|c|}
\hline & \multicolumn{2}{|c|}{$\begin{array}{l}\text { WL } \\
{[\%]}\end{array}$} & \multicolumn{2}{|c|}{$\begin{array}{c}\text { TA } \\
{[\%]}\end{array}$} & \multicolumn{2}{|c|}{$\begin{array}{l}\text { SS } \\
{[\%]}\end{array}$} & \multicolumn{2}{|c|}{$\begin{array}{l}\text { RS } \\
{[\%]}\end{array}$} & \multicolumn{2}{|c|}{ MI } & \multicolumn{2}{|c|}{$\begin{array}{l}\text { Lycopene } \\
{\left[\mathrm{mg} \mathrm{kg}^{-1}\right]}\end{array}$} \\
\hline Initial & \multicolumn{2}{|c|}{-} & \multicolumn{2}{|c|}{$0.47 \pm 0.05$} & \multicolumn{2}{|c|}{$3.01 \pm 0.42$} & \multicolumn{2}{|c|}{$2.85 \pm 0.12$} & \multicolumn{2}{|c|}{$6.27 \pm 0.70$} & \multicolumn{2}{|c|}{$9.22 \pm 1.88$} \\
\hline Days & 8 & 15 & 8 & 15 & 8 & 15 & 8 & 15 & 8 & 15 & 8 & 15 \\
\hline C & 1.22 & 2.25 & 0.35 & $0.36 b$ & 2.78 & $2.77 \mathrm{~b}$ & 2.81 & 2.75 & 7.99 & 6.69 & $20.4 a$ & $52.9 \mathrm{ab}$ \\
\hline $\mathrm{Z}$ & 1.40 & 2.56 & 0.38 & $0.34 a$ & 2.37 & $2.02 a$ & 2.80 & 2.80 & 7.44 & 7.25 & $32.1 b$ & $62.5 b$ \\
\hline $\mathrm{Z}-\mathrm{Cu} / \mathrm{Zn}$ & 1.40 & 2.36 & 0.39 & $0.34 a$ & 2.52 & $2.08 \mathrm{a}$ & 2.82 & 2.79 & 7.33 & 7.31 & $21.3 a$ & $49.5 a$ \\
\hline
\end{tabular}

\footnotetext{
${ }^{1}$ Values are the mean \pm standard error for the replicates. Different letters for the same column indicate significant
} differences $(\mathrm{P}<0.05)$.

Our results indicate that weight loss is mainly a consequence of mass transfer of water vapor from fruit into the headspace of glass desiccators without a significant influence of respiration or zeolite materials. On the other hand, Bailén et al. [32] and Domínguez et al. [38] reported lower weight losses 
for tomatoes preserved under modified atmosphere packaging using ethylene sorbents in comparison with our results.

Approximately $45 \%$ of the total solids in tomato fruit is composed of soluble solids, predominantly reducing sugars (Table 3). Zeolites did not alter the evolution of reducing sugars during tomato storage. A previous study has shown that the main free sugars of commercial tomato varieties are reducing sugars with a negligible amount of sucrose [39]. Moreover, both titratable acidity and soluble solids content are essential quality parameters for tomatoes showing a similar behavior with a significant decrease during the second half of postharvest storage in case of natural and modified zeolites (Table 3). Increased $\mathrm{CO}_{2}$ and $\mathrm{C}_{2} \mathrm{H}_{4}$ production, after one week for tomatoes stored in the presence of both zeolites, may trigger the decomposition of organic acids and part of the soluble solids. In particular, citrate and isocitrate concentrations diminished at later stages of fruit ripening [40]. In addition, stimulation of ethylene production by bruising of tomato fruit yielded a significant decrease of $15.3 \%$ of titratable acidity in locule tissue compared with non-impacted tissue [41]. According to the initial maturity index of 6.27, the quality of raw material belongs to suitable red fruit genotype class [39] with a slight increase due to the loss of titratable acidity during ripening (Table 3).

Fresh-market tomatoes commonly harvested at mature green or breaker stage become soft as ripening proceeds during storage. For this kind of tomato, texture is one of the most important quality attributes, influenced by both skin strength and flesh firmness. Skin strength depends on the force at the bioyield point $\left(\mathrm{F}_{\text {crit }}\right)$, required to punch through the pericarp of tomatoes. Skin strength drops rapidly during the first stage of storage followed by a slower decrease without significant difference between treatments (Table 4). Flesh firmness or mesocarp strength can be calculated from the apparent modulus of elasticity and the Poisson's ratio [42]. Natural zeolite significantly reduced apparent modulus of elasticity at the end of storage (Table 4), which could be attributed to an increased ethylene concentration of about $20 \%$ compared to control tomatoes. Ethylene is able to stimulate the activity of cell wall degrading enzymes by the induction of ethylene responsive genes encoding for pectin methyl esterase, cellulase and polygalacturonase [43]. Softening of fruit flesh is mainly attributed to the degradation of protopectins, which may result in reduced integrity of cell wall components, loss of membrane integrity, and cell turgor. This, in turn, affects shelf-life and consumers' acceptance of tomatoes.

Table 4. Texture and color evolution of tomatoes stored at $20^{\circ} \mathrm{C}$ without (control), in the presence of zeolite $(\mathrm{Z})$ or modified zeolite $(\mathrm{Z}-\mathrm{Cu} / \mathrm{Zn})^{1}$.

\begin{tabular}{|c|c|c|c|c|c|c|c|c|c|c|c|c|}
\hline & \multicolumn{2}{|c|}{$\begin{array}{l}F_{\text {crit }} \\
{[N]}\end{array}$} & \multicolumn{2}{|c|}{$\begin{array}{c}\mathrm{E} \\
{[\mathrm{MPa}]}\end{array}$} & \multicolumn{2}{|c|}{$\mathbf{L}^{*}$} & \multicolumn{2}{|c|}{$a^{*}$} & \multicolumn{2}{|c|}{$\mathbf{b}^{*}$} & \multicolumn{2}{|c|}{$\begin{array}{l}h_{a b} \\
{\left[{ }^{\circ}\right]}\end{array}$} \\
\hline Initial & 12.97 & 2.01 & 1.31 & 0.26 & 54. & 1.8 & -5.2 & \pm 1.5 & 28.2 & $=1.0$ & 100. & $=1.9$ \\
\hline Days & 8 & 15 & 8 & 15 & 8 & 15 & 8 & 15 & 8 & 15 & 8 & 15 \\
\hline C & 7.05 & 6.98 & 1.55 & $1.38 \mathrm{~b}$ & 46.9 & 42.0 & $8.3 a$ & $19.4 \mathrm{a}$ & 24.2 & $21.4 a$ & $70.5 b$ & 48.1 \\
\hline Z & 7.25 & 7.36 & 1.19 & $0.89 a$ & 45.4 & 43.0 & $21.5 b$ & $26.1 \mathrm{~b}$ & 23.2 & $23.9 \mathrm{~b}$ & 47.3a & 42.6 \\
\hline $\mathrm{Z}-\mathrm{Cu} / \mathrm{Zn}$ & 7.70 & 6.75 & 1.40 & $1.29 b$ & 47.3 & 44.1 & $7.8 \mathrm{a}$ & $20.8 \mathrm{a}$ & 25.1 & $24.1 \mathrm{~b}$ & $72.3 b$ & 49.1 \\
\hline
\end{tabular}

\footnotetext{
${ }^{1}$ Values are the mean \pm standard error for the replicates. Different letters for the same column indicate significant differences $(\mathrm{P}<0.05)$.
}

Color is the most important external attribute to assess tomato ripeness and shelf-life, being the major factor for consumers' purchase decision. In this study, ripening is accompanied by a loss of green orange color $(0 \mathrm{~d})$ associated with the breaker stage and the development of pink $(8 \mathrm{~d})$ and light red color characteristics ( $15 \mathrm{~d}$ ) for modified zeolite and control tomatoes. Moreover, tomatoes treated with natural zeolite evolve an accelerated color change expressed by the development of light red $(8 \mathrm{~d})$ and red color characteristics ( $15 \mathrm{~d}$ ) according to USDA color standards [44]. In addition, the greatest effect on delaying color development in tomatoes was found for zeolite that incorporates copper and zinc cations, except for the color parameter $\mathrm{a}^{*}$ after $15 \mathrm{~d}$ (Table 4). Red color development is the result of chlorophyll degradation, as well as the synthesis of carotenoids, as chloroplasts are converted into 
chromoplasts [40]. The degree of greenness or redness $\left(\mathrm{a}^{*}\right)$ is changing from negative (green) to positive (red) values during tomato storage. In particular, red color evolution is promoted by natural zeolite with strong increase of $\mathrm{a}^{*}$ values during the first eight days in contrast to modified zeolite and control treatments (Table 4$)$. The degree of yellowness $\left(b^{*}\right)$ decreased just a little during fruit ripening with significantly higher values for zeolite samples at the final ripening stage (Table 4). This suggests better retention of yellow pigments due to the presence of zeolites. Lightness $\left(\mathrm{L}^{*}\right)$ gradually declined during postharvest storage, where zeolites did not influence this quality parameter (Table 4). Moreover, hue angle $\left(h_{a b}\right)$ correlates well with consumers' perception of fruit color. A hue angle greater than $90^{\circ}$ in the second quadrant of the $L^{*} a^{*} b^{*}$ color space represents the initial condition of raw material and indicates a green orange color of tomato surface (Table 4). During ripening, hue decreased rapidly up to $47^{\circ}$ for zeolite treated tomatoes corresponding to light red color, while hue of the other tomato samples was in the $70-72^{\circ}$ range after $8 \mathrm{~d}$ of storage, which corresponds to yellowish-pink color (Table 4). Natural zeolite promotes red color evolution of tomatoes, which coincides with an increase of $100 \%$ in the amount of $\mathrm{CO}_{2}$ produced after $8 \mathrm{~d}$ of storage in comparison to control. The inclusion of copper and zinc cations within the zeolite framework is favorable to avoid excessive red color development of tomatoes treated by natural zeolite.

Health benefits were associated to the consumption of a diet rich in lycopene, a fat-soluble carotenoid with excellent antioxidant properties [45]. The accumulation of lycopene occurs due to the conversion of chloroplasts into chromoplasts, coupled to the synthesis of this red pigment from 2 geranyl-geranyl pyrophosphate via phytoene, phytofluene, $\xi$-carotene, and prolycopene intermediaries [40]. According to Sipos et al. [45], lycopene content and antioxidant capacity of tomatoes correlated positively to both surface and puree colors. This suggests that lycopene content depends on tomato ripeness. Our results indicate that lycopene content of tomatoes increased progressively over time ranging between $9.2 \mathrm{mg} \mathrm{kg}^{-1}$ and $62.5 \mathrm{mg} \mathrm{kg}^{-1}$ (Table 4). Moreover, lycopene content had a strong inverse correlation with hue having a Pearson's coefficient of $-0.887(\mathrm{P}<0.0001)$, while lycopene synthesis was also affected by ethylene and $\mathrm{CO}_{2}$ levels inside the gas atmosphere of the glass desiccators with Pearson's correlation coefficients of $0.787(\mathrm{P}=0.063)$ and $0.782(\mathrm{P}=0.066)$, respectively. In addition, natural zeolite yields a significantly higher increase of lycopene synthesis compared to tomatoes stored in the presence of modified zeolite (Table 4).

Finally, improved ripening of tomatoes in the presence of natural zeolite is unfavorable if our goal is to increase postharvest shelf-life, while the incorporation of copper and zinc cations to the support lattice slows down fruit ripening being therefore an emergent postharvest technology that may create new commercial opportunities.

\section{Conclusions}

Natural zeolite composed of $53 \%$ clinoptilolite, $40 \%$ mordenite, and $7 \%$ quartz promoted tomato ripening according to the quality parameters titratable acidity, soluble solids, apparent modulus of elasticity and greenness or redness degree after $15 \mathrm{~d}$ of tomato storage. The introduction by ion-exchange of copper and zinc cations in zeolite followed by calcination treatments resulted in a modified zeolite that was able to remove $57 \%$ of ethylene after $8 \mathrm{~d}$ of storage and to shift the $\mathrm{CO}_{2}$ production for $6 \mathrm{~d}$ compared to control. Chromatic characteristics, such as hue and greenness or redness degree, and lycopene content improved after $8 \mathrm{~d}$ and apparent modulus of elasticity and lycopene content after $15 \mathrm{~d}$ of storage. DRIFTS operando studies showed that the adsorption mechanism takes mainly place by the interaction of ethylene molecules with Brønsted active sites. However, DRIFTS results also indicated that water molecules compete with ethylene for the active sorption sites, decreasing the adsorption capacity towards ethylene. Doping the zeolite with copper and zinc cations seems to favor ethylene adsorption mechanism by cation- $\pi$ interactions, improving postharvest quality of tomatoes. Natural zeolite modified with copper and zinc cations may be used as a low cost and non-toxic alternative ethylene scavenger to commercial ones available in the market. Finally, the use of 
ultraviolet light could be explored to degrade bound ethylene and make free the active sorption sites of modified zeolite.

Author Contributions: Conceptualization, H.V. and J.d.B.; methodology, V.S., C.L., and P.M.; validation, H.V., J.d.B., and P.M.; formal analysis, F.A.-J. and N.A.; investigation, A.G., C.L., N.A., and F.A.-J.; data curation, V.S. and F.A.-J.; writing—original draft preparation, J.d.B.; writing—review and editing, H.V. and P.M.; supervision, H.V.; project administration, H.V.; funding acquisition, H.V. All authors have read and agreed to the published version of the manuscript.

Funding: This research was funded by Comisión Nacional de Investigación Científica y Tecnológica of Chile CONICYT, FONDECYT Regular grant number 1170694. The mobility of F.A. was funded by Fondo Especial de Actividades Académicas UCSC 2019-II.

Acknowledgments: The authors would like to acknowledge Jaime Fuentealba for providing the tomatoes.

Conflicts of Interest: The authors declare no conflict of interest. The funders had no role in the design of the study; in the collection, analyses, or interpretation of data; in the writing of the manuscript, or in the decision to publish the results.

\section{References}

1. FAO. Food and Agricultural Data. Available online: http://www.fao.org/faostat/en/ (accessed on 2 November 2019).

2. Saltveit, M.E. Effect of ethylene on quality of fresh fruits and vegetables. Postharvest Biol. Technol. 1999, 15, 279-299. [CrossRef]

3. Pathak, N.; Caleb, O.J.; Geyer, M.; Herppich, W.B.; Rauh, C.; Mahajan, P.V. Photocatalytic and photochemical oxidation of ethylene: Potential for storage of fresh produce-A review. Food Bioprocess Technol. 2017, 10, 982-1001. [CrossRef]

4. Zhang, J.; Cheng, D.; Wang, B.; Khan, I.; Ni, Y. Ethylene control technologies in extending postharvest shelf life of climateric fruit. J. Agric. Food Chem. 2017, 65, 7308-7319. [CrossRef]

5. Álvarez-Hernández, M.H.; Artés-Hernández, F.; Ávalos-Belmontes, F.; Castillo-Campohermoso, M.A.; Contreras-Esquivel, J.C.; Ventura-Sobrevilla, J.M.; Martínez-Hernández, G.B. Current scenario of adsorbent materials used in ethylene scavenging systems to extend fruit and vegetable postharvest life. Food Bioprocess Technol. 2018, 11, 511-525. [CrossRef]

6. Saltveit, M.E. Is it possible to find an optimal controlled atmosphere? Postharvest Biol. Technol. 2003, 27, 3-13. [CrossRef]

7. Vermeiren, L.; Devlieghere, F.; Van Beest, M.; De Kruijf, N.; Debevere, J. Developments in the active packaging of foods. Trends Food Sci. Technol. 1999, 10, 77-86. [CrossRef]

8. Attar, K.; Demey, H.; Bouazza, D.; Sastre, A.M. Sorption and desorption studies of Pb(II) and Ni(II) from aqueous solutions by a new composite based on alginate and magadiite materials. Polymers 2019, 11, 340. [CrossRef] [PubMed]

9. Tas, C.E.; Hendessi, S.; Baysal, M.; Unal, S.; Cebeci, F.C.; Menceloglu, Y.Z.; Unal, H. Halloysite nanotubes/polyethylene nanocomposites for active food packaging materials with ethylene scavenging and gas barrier properties. Food Bioprocess Technol. 2017, 10, 789-798. [CrossRef]

10. García-García, I.; Taboada-Rodríguez, A.; López-Gomez, A.; Marín-Iniesta, F. Active packaging of cardboard to extend the shelf life of tomatoes. Food Bioprocess Technol. 2013, 6, 754-761. [CrossRef]

11. Álvarez-Hernández, M.H.; Martínez-Hernández, G.B.; Ávalos-Belmontes, F.; Rodríguez-Hernández, A.M.; Castillo-Campohermoso, M.A.; Artés-Hernández, F. An innovative ethylene scrubber made of potassium permanganate loaded on a protonated montmorillonite: A case study on blueberries. Food Bioprocess Technol. 2019, 12, 524-538. [CrossRef]

12. Spricigo, P.C.; Foschini, M.M.; Ribiero, C.; Corrêa, D.S.; Ferreira, M.D. Nanoscaled platforms based on $\mathrm{SiO}_{2}$ and $\mathrm{Al}_{2} \mathrm{O}_{3}$ impregnated with potassium permanganate use color changes to indicate ethylene removal. Food Bioprocess Technol. 2017, 10, 1622-1630. [CrossRef]

13. Martínez-Romero, D.; Bailén, G.; Serrano, M.; Guillén, F.; Valverde, J.M.; Zapata, P.; Casillo, S.; Valero, D. Tools to maintain postharvest fruit and vegetable quality through the inhibition of ethylene action: A review. Crit. Rev. Food Sci. Nutr. 2007, 47, 543-560. [CrossRef] [PubMed] 
14. Smith, A.W.J.; Poulston, S.; Rowsell, L.; Terry, L.A.; Anderson, J.A. A new-palladium-based ethylene scavenger to control ethylene-induced ripening of climacteric fruit. Platin. Met. Rev. 2009, 53, 112-122. [CrossRef]

15. Álvarez-Hernández, M.H.; Martínez-Hernández, G.B.; Avalos-Belmontes, F.; Castillo-Campohermoso, M.A.; Contreras-Esquivel, J.C.; Artés-Hernández, F. Potassium permanganate-based ethylene scavengers for fresh horticultural produce as an active packaging. Food Eng. Rev. 2019, 11, 159-183. [CrossRef]

16. Keller, N.; Ducamp, M.N.; Robert, D.; Keller, V. Ethylene removal and fresh product storage: A challenge at the frontiers of chemistry. Toward an approach by photocatalytic oxidation. Chem. Rev. 2013, 113, 5029-5070. [CrossRef]

17. Terry, L.A.; Ilkenhans, T.; Poulston, S.; Rowsell, L.; Smith, A.W.J. Development of new palladium-promoted ethylene scavenger. Postharvest Biol. Technol. 2007, 45, 214-220. [CrossRef]

18. Cao, J.; Li, X.; Wu, K.; Jiang, W.; Qu, G. Preparation of a novel PdCl2-CuSO4-based ethylene scavenger supported by acidified activated carbon powder and its effects on quality and ethylene metabolism of broccoli during shelf-life. Postharvest Biol. Technol. 2015, 99, 50-57. [CrossRef]

19. De Chiara, M.L.V.; Pal, S.; Licciulli, A.; Amodio, M.L.; Colelli, G. Photocatalytic degradation of ethylene on mesoporous $\mathrm{TiO}_{2} / \mathrm{SiO}_{2}$ nanocomposites: Effects on the ripening of mature green tomatoes. Biosyst. Eng. 2015, 132, 61-70. [CrossRef]

20. Zhu, Z.; Zhang, Y.; Shang, Y.; Wen, Y. Electrospun nanofibers containing $\mathrm{TiO}_{2}$ for the photocatalytic degradation of ethylene and delaying postharvest ripening of bananas. Food Bioprocess Technol. 2019, 12, 281-287. [CrossRef]

21. Pathak, N.; Caleb, O.J.; Rauh, C.; Mahajan, P.V. Efficacy of photocatalysis and photolysis systems for the removal of ethylene under different storage conditions. Postharvest Biol. Technol. 2019, 147, 68-77. [CrossRef]

22. Nájera, C.; Guil-Guerrero, J.L.; Enríquez, L.J.; Álvaro, J.E.; Urrestarazu, M. LED-enhanced dietary and organoleptic qualities in postharvest tomato fruit. Postharvest Biol. Technol. 2018, 145, 151-156. [CrossRef]

23. Abreu, N.J.; Valdés, H.; Zaror, C.A.; Azzolina-Jury, F.; Meléndrez, M.F. Ethylene adsorption onto natural and transition metal modified Chilean zeolite: An operando DRIFTS approach. Microporous Mesoporous Mater. 2019, 274, 138-148. [CrossRef]

24. Valdés, H.; Solar, V.A.; Cabrera, E.H.; Veloso, A.F.; Zaror, C.A. Control of released volatile organic compounds from industrial facilities using natural and acid-treated mordenites: The role of acidic surface sites on the adsorption mechanism. Chem. Eng. J. 2014, 244, 117-127. [CrossRef]

25. Zhu, Z.; Chen, Y.; Shi, G.; Zhang, X. Selenium delays tomato fruit ripening by inhibiting ethylene biosynthesis and enhancing the antioxidant defense system. Food Chem. 2017, 219, 179-184. [CrossRef]

26. ASAE. ASAE S368.2: Compression test of food materials of convex shape. In ASAE Standards 1991: Standards, Engineering Practices, and Data; American Society of Agricultural Engineers: Joseph, MI, USA, 1991; pp. 402-405.

27. Adegoroye, A.S.; Jolliffe, P.A.; Tung, M.A. Textural characteristics of tomato fruit (Lycopersicon esculentum) affected by sunscald. J. Sci. Food Agric. 1989, 49, 95-102. [CrossRef]

28. Li, Z.; Li, P.; Yang, H.; Liu, J. Internal mechanical damage prediction in tomato compression using multiscale finite element models. J. Food Eng. 2013, 116, 639-647. [CrossRef]

29. AOAC. Official Methods of Analysis; Association of Official Analytical Chemists: Washington, DC, USA, 1990; p. 1141.

30. Schneider, F. Sugar Analysis: Official and Tentative Methods Recommended by the International Commission for Uniform Methods of Sugar Analysis (ICUMSA); The International Commission for Uniform Methods of Sugar Analysis: Peterborough, UK, 1979; pp. 45-55.

31. Fish, W.W.; Perkins-Veazie, P.; Collins, J.K. A quantitative assay for lycopene that utilizes reduced volumes of organic solvents. J. Food Compos. Anal. 2002, 15, 309-317. [CrossRef]

32. Bailén, G.; Guillén, F.; Castillo, S.; Serrano, M.; Valero, D.; Martínez-Romero, D. Use of activated carbon inside modified atmosphere packages to maintain tomato fruit quality during cold storage. J. Agric. Food Chem. 2006, 54, 2229-2235. [CrossRef]

33. Patdhanagul, N.; Seithanratana, T.; Rangsriwatananon, K. Ethylene adsorption on cationic surfactant modified zeolite NaY. Microporous Mesoporous Mater. 2010, 131, 97-102. [CrossRef]

34. Sue-aok, N.; Srithanratana, T.; Rangsriwatananon, K.; Hengrasmee, S. Study of ethylene adsorption on zeolite NaY modified with group I metal ions. Appl. Surf. Sci. 2010, 256, 3997-4002. [CrossRef] 
35. Salehi, S.; Anbia, M. Characterization of CPs/Ca-exchanged FAU-and LTA-type zeolite nanocomposites and their selectivity for $\mathrm{CO}_{2}$ and $\mathrm{N}_{2}$ adsorption. J. Phys. Chem. Solids 2017, 110, 116-128. [CrossRef]

36. Lavalley, J.C. Infrared spectrometric studies of the surface basicity of metal oxides and zeolites using adsorbed probe molecules. Catal. Today 1996, 27, 377-401. [CrossRef]

37. Hefti, M.; Marx, D.; Joss, L.; Mazzotti, M. Model-based process design of adsorption processes for $\mathrm{CO}_{2}$ capture in the presence of moisture. Energy Procedia 2014, 63, 2152-2159. [CrossRef]

38. Domínguez, I.; Lafuente, M.T.; Hernández-Muñoz, P.; Gavara, R. Influence of modified atmosphere and ethylene levels on quality attributes of fresh tomatoes (Lycopersicon esculentum Mill.). Food Chem. 2016, 209, 211-219. [CrossRef] [PubMed]

39. Raiola, A.; Pizzolongo, F.; Manzo, N.; Montefusco, I.; Spigno, P.; Romano, R.; Barone, A. A comparative study of the physico-chemical properties affecting the organoleptic quality of fresh and thermally treated yellow tomato ecotype fruit. Int. J. Food Sci. Technol. 2018, 53, 1219-1226. [CrossRef]

40. Aivalakis, G.; Katinakis, P. Biochemistry and molecular physiology of tomato and pepper fruit ripening. In The Fruiting Species of the Solanaceae. The European Journal of Plant Science and Biotechnology; Passam, H., Ed.; Global Science Books: Isleworth, UK, 2008; Volume 2, pp. 145-155.

41. Moretti, C.L.; Sargent, S.A.; Huber, D.J.; Calbo, A.G.; Puschmann, R. Chemical composition and physical properties of pericarp, locule, and placental tissues of tomatoes with internal bruising. J. Am. Soc. Hortic. Sci. 1998, 123, 656-660. [CrossRef]

42. Figura, L.O.; Teixeira, A.A. Food Physics. Physical Properties-Measurement and Applications; Springer: Berlin, Germany, 2007; pp. 121-203.

43. Bu, J.; Yu, Y.; Aisikaer, G.; Ying, T. Postharvest UV-C irradiation inhibits the production of ethylene and the activity of cell wall-degrading enzymes during softening of tomato (Lycopersicon esculentum L.) fruit. Postharvest Biol. Technol. 2013, 86, 337-345. [CrossRef]

44. Batu, A. Determination of acceptable firmness and colour values of tomatoes. J. Food Eng. 2004, 61, 471-475. [CrossRef]

45. Sipos, L.; Orbán, C.; Bálint, I.; Csambalik, L.; Divéky-Ertsey, A.; Gere, A. Colour parameters as indicators of lycopene and antioxidant activity traits of cherry tomatoes (Solanum lycopersicum L.). Eur. Food Res. Technol. 2017, 243, 1533-1543. [CrossRef] 